\title{
PERAN GREEN TRUST MEMEDIASI PENGARUH GREEN BRAND IMAGE TERHADAP GREEN BRAND EQUITY PRODUK BALI RATIH
}

\author{
Made Surya Winangun ${ }^{1}$ \\ Nyoman Nurcaya ${ }^{2}$
}

\author{
${ }^{1,2}$ Fakultas Ekonomi dan Bisnis Universitas Udayana, Bali, Indonesia \\ email: suryawinangun4@gmail.com
}

\begin{abstract}
ABSTRAK
Brand equity merupakan penambahan nilai padanama merek sebuah produk. Suatu brand dengan ekuitasyang tinggi maka brand tersebut akan memiliki daya saing yang kuat di pasaran, sehingga perusahaan menggangap bahwa ekuitas adalah aspek penting dalam sebuah brand. Penelitian ini bertujuan untuk memperoleh bukti empiris mengenai pengaruh green brand image terrhadap green brand equityyang dimediasi oleh green trust. Populasi yang digunakan dalam penelitian ini adalah seluruh konsumen produk merek Bali Ratih yang berdomisili di Kota Denpasar.Penentuan sampel dilakukan dengan teknik non probability sampling dengan metode purposive sampling, selanjutnya diperoleh sampel sebanyak 100 responden. Data dianalisis menggunakan analisis jalur. Hasil pengujian penelitian adalahterdapat pengaruh positif antara green brand imagedan green trust, terdapat pengaruh positif antara green brand imagedangreen brand equity, terdapat pengaruh positif antara green trustdangreen brand equity dan green trust merupakan pemediasi dalam hubungan green brand imagedengan green brand equity.
\end{abstract}

Kata Kunci: green trust, green brand image, green brand equity

\begin{abstract}
Brand equity is often described as the value of a brand name that is added into a product. The higher the equity of a brand, the brand competitiveness will be stronger in the market, therefore, the equity of the brand is an aspect that must be strengthened by a company. This study aims to obtain empirical evidence about the role of green trust mediating the effect of green brand image on green brand equity. The population used in this study were all consumers in the city of Denpasar who had used Bali Ratih brand products. The method of determining the sample is done by using non-probability sampling technique with purposive sampling method. Thus, respondents numbered 100 people. The data analysis technique used is path analysis. The test results state that green brand image has a positive effect on green trust, green brand image has a positive effect on green brand equity, green trust has a positive effect on green brand equity and green trust is a mediating effect of green brand image on green brand equity

Keywords: green trust, green brand image, green brand equity
\end{abstract}




\section{PENDAHULUAN}

Masalah terkini yang dihadapi masyarakat yang dapat berdampak positif bahkan berdampak negatif bagi kondisi lingkungan adalah isu pemanasan global (Shaputra, 2013). Dampak dari pemanasan global dapat berimbas padasebagian besar aspek kehidupan. Seperti saat ini, persaingan dunia bisnis menuntut perusahaan mulai mengadopsi konsep pemasaran hijau (green marketing) dan mengatasi masalah lingkungan sebagai sumber keunggulan kompetitif dalam mengembangkan dan mempromosikan produk hijau guna memenuhi permintaan konsumen yang sadar akan kelestarian lingkungan (Tan, 2011).

Adanya efek dari berubahnya kondisi cuaca dan perubahan perilaku masyarakat yang mulai memperlihatkan kepedulian terhadap lingkungan, sehingga masyarakat mulai menerapkan Green Marketing yang dianggap dapat meningkatkan kualitas kepercayaan dan perilaku positif bagi lingkungan hidup (Tariq, 2014). Pertimbangan akan lingkungan hidup dengan cepat muncul sebagai gagasan utama karena adanya pemanasan global ,yang menyebabkan perusahaan kedepannya lebih meninjau dalam mengambil keuntungan dari peluang lingkungan, itu sebabnya kini beberapa perusahaan sudah mulai melakukan Green Marketing. Green Marketing adalah segala bentuk kegiatan yang berkaitan dengan pemasaran dengan fokus kepedulianpada lingkungan. Kegiatan tersebut mencakup aktif dalam promosi dan produksi produk dan pelayanan yang dapat memanjakan konsumen sehingga memberi kepuasan tanpa memberi dampak negatif pada lingkungan (Arseculeratne dan Yazdanifard, 2014).

Pemanasan global yang terjadi, menyebabkankonsumen mulai berpikir untuk beralih untuk mengkonsumsi hasil produksiyang aman bagi lingkungan, namun tantangan yang dihadapi oleh produk yang ramah lingkungan adalah terkait respon kunsumen di pasaran, sehingga pemasar perlu lebih mempromosikan produk tersebut agar konsumen percaya akan produk yang ditawarkan. Chen (2010) menyatakan bahwa terdapatlima alasan kenapa perusahaan mulai mnerapkan green marketing yaitu untuk semakin menumbuhkan nama baik perusahaan, memberi peningkatan pada nilai suatu produk, mampu memanfaatkan peluangdari kelestarian lingkungan untuk menambah keuntungan, peningkatan keunggulan kompetitif sehingga mampu menghadapi persaingan, dan memudahkan perusahaan untuk mengikuti tren lingkungan.

Salah satu sektor industri yang saat ini cukup banyak menggunakan sistem green marketing adalah perusahaan dari sektor produk kecantikan, bisa dilihat produk-produk kecantikan saat ini sangat banyak yang memperlihatkan unsurunsur kealamiannya walaupun ada juga beberapa perusahaan yang enggan untuk melakukannya. Penggunaan unsur-unsur kimia pada produk kecantikan tentunya dapat merusak siklus alam yang akan meningkatkan pemanasan global dan tentunya para penggunanya, terdapat cukup banyak kasus di Indonesia tentang produkproduk kecantikan yang membuat kulit konsumennya terbakar, salah satu faktor penyebab terjadinya hal itu adalah adanya zat-zat kimia yang terkandung didalam produk kosmetik yang tidak cocok dengan tubuh dan tentu akan membahayakan bagi konsumen yang menggunakan produk tersebut.

Berdasarkan hasil pengawasan, pengambilan sampel, dan pengujian laboratorium oleh BPOM RI sejak pertengahan Tahun 2016, ditemukan sebanyak 
40 (empat puluh) item produk kosmetik yang mengandung bahan berbahaya, diantaranya merkuri, hidrokinon, pewarna tekstil, dan asam retinoat.

Tabel 1.

Produk Kosmetik Mengandung Bahan Berbahaya

\begin{tabular}{|c|c|c|c|}
\hline No & Nama & Produsen/importer & $\begin{array}{c}\text { Bahan } \\
\text { berbahaya }\end{array}$ \\
\hline 1 & La Bella Day Cream & $\begin{array}{l}\text { Taiwan oleh CV Crystal } \\
\text { Beauty - Jakarta }\end{array}$ & Merkuri \\
\hline 2 & La Bella Night Cream & $\begin{array}{l}\text { Taiwan oleh CV Crystal } \\
\text { Beauty - Jakarta }\end{array}$ & Merkuri \\
\hline 3 & $\begin{array}{l}\text { La Widya Curcumin Night } \\
\text { Cream }\end{array}$ & $\begin{array}{l}\text { Taiwan oleh PT Sinar Dios } \\
\text { Abadi - Jakarta }\end{array}$ & Merkuri \\
\hline 4 & Eco-Agen Day Cream & $\begin{array}{l}\text { Pasifik Osean Indonesia - } \\
\text { Jakarta }\end{array}$ & Hidrokinion \\
\hline 5 & Eco-Agen Night Cream & $\begin{array}{l}\text { Pasifik Osean Indonesia - } \\
\text { Jakarta }\end{array}$ & Hidrokinion \\
\hline 6 & Esther Day Cream & $\begin{array}{l}\text { Pasifik Osean Indonesia - } \\
\text { Jakarta }\end{array}$ & Asam retinoat \\
\hline 7 & Esther Night Cream & $\begin{array}{l}\text { Pasifik Osean Indonesia - } \\
\text { Jakarta }\end{array}$ & Asam retinoat \\
\hline 8 & Widya Day Cream Curcuma & $\begin{array}{l}\text { Pasifik Osean Indonesia - } \\
\text { Jakarta }\end{array}$ & Pewarna tekstil \\
\hline 9 & Widya Night Cream Curcuma & $\begin{array}{l}\text { Pasifik Osean Indonesia - } \\
\text { Jakarta }\end{array}$ & Pewarna tekstil \\
\hline 10 & DR Night Cream & $\begin{array}{l}\text { CV Bernita Ayu - } \\
\text { Tulungagung }\end{array}$ & Pewarna tekstil \\
\hline
\end{tabular}

Sumber: BPOM RI, 2016

Berbagai risiko dan efek yang tidak diinginkan dari penggunaan bahan berbahaya dalam kosmetik menurut BPOM RI adalah: 1) Merkuri/Air raksa termasuk logam berat berbahaya yang dapat bersifat racun. Bahan kimia merkuri bisanya disalah gunakan sebagai pemutih wajah. Pemakaian merkuri dapat menyebabkan bintik-bintik hitam pada kulit, alergi dan juga menyebabkan penyakit kanker, 2) hidrokinon termasuk golongan obat keras, seringkali disalahgunakan sebagai bahan pencerah kulit. Untuk produk kosmetik yang mengandung 
hidrokinon, dampaknya bila digunakan dapat mengiritasi kulit, menyebabkan kemerahan pada kulit (kulit terbakar), terlebih lagi bila saat penggunaannya pada kulit juga ikut terpapar sinar matahari, maka dampaknya akan menimbulkan kemerahan permanen pada kulit, 3) asam retinoat banyak disalahgunakan dalam produk perawatan kulit. Asam retinoat dicampurkan ke dalam kosmetik untuk memudahkan pengelupasan kulit. Dampak penggunaan produk kosmetik yang mengandung asam retinoat adalah dapat menyebabkan timbulnya pengelupasan pada kulit yang cukup parah, 4) pewarna tekstil seperti Merah K3 dan Merah K10 juga sering disalahgunakan sebagai bahan pewarna dalam produk kosmetik berupa masker wajah. Produk kosmetik yang mengandung pewarna tekstil bersifat karsinogenik, dan bila digunakan, dampaknya dapat menyebabkan kanker dan kerusakan hati.

Melihat fenomena ditemukan sebanyak 40 jenis kosmetik dengan kandungan bahan yang membahayakan, sepertimengandung hidrokinon, pewarna tekstil, merkuri, sertaasam retinoat. Produk Bali Ratih Bali membuat gerakan baru, Bali Ratih adalah usaha yang bergerak dalam bidang penjualan produk perawatan tubuh asli dari Bali yang terbuat dari bahan-bahan alami dari alam, yang diproses menggunakan mesin yang berteknologi canggihdan terjaga kebersihannyasehingga menghasilkan produk yang higenis dimana didalamnya mengandung bahan alamiyang diperoleh dari extract tumbuhan seperti bunga dan buah. Menjadikan produk Bali Ratih produk berkualitas terbaik yang aman bagi kulit. Produk Bali Ratih dijamin bebas dari bahan kimia berbahaya seperti merkuri, hidrokinon, asam retinoat dan pewarna tekstil. Merek ini sudah terkenal dalam industri produk kecantikan ramah lingkungan dan terdaftar di Depkes RI \& Badan Pemeriksaan Obat dan Makanan sehingga legal dan aman dalam penggunaan.

Bali Ratih mempunyai visi untuk menjadi produk pertama yang ramah lingkungan di Bali yang dikenal oleh masyarakat luas dan memiliki misi membuat produk modern dengan menggunakan bahan-bahan alami dari alam yang diolah dengan teknologi modern. Terdapat empat produk Bali Ratih yaitu, Traditional Body Scrubs Cream, Body Butter, Hand \& Body Lotion, dan Body Mist. Pusat produksi produk Bali Ratih berada di jalan. Purba Indah, Gatot Subroto Barat, Denpasar. (sumberwww.bali-ratih.com).

Bali Ratih yang mengusung produk ramah lingkungan merupakan suatu ciriprodusen produk kecantikan yang menerapkan green marketing. Penerapangreen marketingoleh perusahaan selain dalam halpenawaranhasil produksi yang mendukung kelestarian lingkungan, tetapi juga dalam proses produksinyajuga mengusung konsepyang mendukung kelestarian lingkungan. Fungsi lain dari green marketing dalam produk Bali Ratih adalah memberikan peningkatan bagi nilai merek perusahaan, karena pada dasarnya menciptakan merek yang terkenal di pasaran merupakan tujuan sebagian besar perusahaan. Nilai merek dinilaimampu meningkatkan margin keuntungan dankeunggulan bersaingbagi perusaaan (Delgado-Ballester \& Munuera-Alema'n, 2005)

Dewasa ini, banyak perusahaan diharuskan memiliki tanggungjawab pada kelestarian lingkungan dengan melahirkan merek yang mendukungkelestarian lingkungan dan mempromosikannya ke kalangan masyrakat luas. Oleh karena itu, 
penciptaan image merek dapat digunakan sebagai dasar dalam penentuan persepsi konsumen terhadap ketertarikannya pada merek tertentu.

Chen (2010) menjelaskan bahwa sebuah merek yang digambarkan dengan atribut simbol dan ataunama yang mampu memberikan nilai pada suatu produk untukbertanggungjawabpada lingkungan disebut green brand equity. Ekuitas suatu produkdicerminkan sebagai nilai merek yang ditambahkan pada sebuah produk yang dihasilkan dari kegiatan pemasaran merek tersebut. Ekuitas dari suatu brand yang semakin tinggi juga akan berdampak pada kuatnya daya saing brand tersebut di pasaran, oleh karena itu penting bagi perusahaan untuk memperkuat ekuitas dari suatu brand.

Green brand image dapat dikatakan sebagai sebuah persepsi konsumen mengenai merek yangberkomitmen dan peduli terhadap kelestarian lingkungan (Chen, 2010). Adanya sikap peduli konsumen pada kelestarian lingkungan, konsumen akan lebih tertarik dan menaruh kepercayaan pada brand yang memiliki image positif dalam menjaga kelestarian lingkungan. Produkyang memiliki image positif terkaitdapat menjadiaset perusahaan, karenaakan memberi dampak pada persepsi konsumen yang peduli akan lingkungan. Masalah utama yang harus dipahami adalah bagaimana konsumen dapat percaya pada citra positif suatu merek (Sutrisna, 2008:84).

Penelitian Chen (2010) serta Waluyo dan Didik (2013), membuktikan bahwa terdapat pengaruh positif dan signifikan antara green brand image terhadap green brand equity. Namun, berbeda dari hasil penelitian Allen (2015) serta Naftalia dan Suparna (2017), yang menyatakan bahwa tidak terdapat pengaruh antara green brand image dengan green brand equity. Hasil yang tidak konsisten tersebut mengindikasikan bahwa terdapat variabel lain yang dapat mempengaruhi hubungan kedua variabel tersebut.

Selain dipengaruhi oleh green brand image, faktor penentu green brand equity yaitu green trust (kepercayaan hijau). Green trust merupakan sikap ketergantungan pada sebuah produk atau merek berdasarkan pada rasa yakin yang timbul darikredibilitas terkait kinerja lingkungan Chen (2010). Konsep green trust mencerminkan kepercayaan adalah penting untuk dibangun oleh perusahaan guna menjaga hubungan baik jangka pendek ataupun jangka panjang dengan konsumen. Purnami dan Nurcahya (2015) menyatakan bahwa kepercayaan (trust) berperan penting dalam mempengaruhi hubungan komitmen dan loyalitas pelanggan.Bila konsumen mampu memberikan kepercayaan terhadap suatu perusahaan, maka keuntungan lebih dari sebelumnyaakan diperoleh oleh perusahaan.

Penelitian ini bertujuan untuk memperoleh bukti empiris mengenai peran green trust sebagai pemediasi pengaruh green brand image terhadap green brand equity. Penelitian ini memiliki beberapa manfaat, yaitu mampu memperkaya pengetahuan dalam bidang ilmu manajemen pemasaran, terutama terkait dengan teori green marketing serta bukti empiris terkait pengaruh green brand image pada green brand equity pada produk Bali Ratih yang dimediasi oleh green trust dan dapat memberikan tambahan informasiterkait green product mengenai green trust sebagai pemediasi pengaruh green brand image terhadap green brand equity pada produk merek Bali Ratih. Sehingga perusahaan dapat mengambil keputusan yang 
tepat untuk meningkatkan kepercayaan konsumen dan memperluas ekuitas brand produknya.

Kepedulian pada lingkungan diintegrasikan pada strategi, kebijakan, dan proses manajemen dalam mengelola organisasi atau perusahaan. Dimana kebutuhan dan keinginan masyarakat akan bergantung dari pola pikir masyarakat yang mulai menyadari pentingnya produk yang ramah lingkungan. Hal ini menuntun pengaruh aktivitas pemasaran pada lingkungan alami dan juga mendorong praktek yang meminimalisasi efek yang merugikan sesuai dengan strategi green marketing. Shaputra (2013) juga menyatakan bahwa green marketing adalah proses dari menjual produk atau jasa yang ramah lingkungan melalui cara produksi atau kemasan dengan dasar keuntungan lingkungan. Disamping itu, pada green marketing ditekankan bahwa perlindungan lingkungan bukan berarti menghilangkan kesejahteraan ekonomi, tetapi sebaliknya mendorong pemikiran kembali tentang bagaimana mengaitkan pemasaran dengan perlindungan lingkungan (Batu, 2013).

Dalam menyusun hipotesis penelitian harus didukung oleh kajian teori dan hasil penelitian sebelumnya. Berdasarkan teori green marketing yang merupakanproses dari menjual produk yang peduli pada kelestarian lingkungan melalui proses pembuatan hingga pengemasan dengan dasar keuntungan lingkungan. Green marketing berfokus pada aktivitas melindungi lingkungan tanpa menghilangkan kesejahteraan ekonomi, tetapi memberikan motivasi terkait bagaimana menjalankan pemasaran sekaligus mengkampanyekan kelestarian lingkungan (Batu, 2013).

Mayoritas penelitian sebelumnya menemukan bahwa green brand image berpengaruh secara positif terhadap green trust, tetapi juga terdapat penelitian yang menemukan bahwa green brand image memiliki pengaruh yang negatif terhadap green trust. Semakin komitmen perusahaan terhadap kelestarian lingkungan, maka konsumen yang peduli pada produk tersebut akan semakin percaya. Penelitian Chen (2010) serta Waluyo dan Didik (2013), menemukan bahwa green brand image berpengaruh positif terhadap green trust. Oleh karena itu, penelitian menggunakan hipotesis berikut:

$\mathrm{H}_{1}$ : Green Brand Image berpengaruh positif dan signifikan terhadap Green Trust produk Bali Ratih di Kota Depasar

Menurut Chen (2010), green brand image merupakan persepsi konsumen atas merek yang berkaitan dengan kelestarian lingkungan. Image yang kuat dari suatu brand dapat memberikan ketertarikankonsumen untuk mengkonsumsi produk dari brand tersebut. Penelitian Chen (2010) serta Waluyo dan Didik (2013), menemukanbahwa terdapat perngaruh yang positif antara green

brand image terhadap green trust. Berdasarkan atas kajian penelitian sebelumnya maka dapat dirumuskan hipotesis sebagai berikut:

$\mathrm{H}_{2}$ : Green Brand Image Berpengaruh Positif Dan Signifikan Terhadap Green Brand Equity Produk Bali Ratih Di Kota Denpasar

Penelitian Chen (2010) menyatakan bahwa green trust adalah keinginan untuk ketergantungan pada sebuah produk atau merek yang didasari pada harapan 
yang berasal dari kredibilitas, perbuatan baik, dan kecakapan tetang kinerja lingkungan. Hal penting yang dimiliki oleh sebuah brand adalah adanya kepercayaan karena konsumen akan memberikan nilai tambah pada brand tersebut. Konsumen yang merasa bahwa produk yang digunakan tidak sesuai harapan maka konsumen kemungkinan besar tidak akan kembali menggunakan merek tersebut, maka dari itu kepercayaan ditunjukkan oleh komitmen konsumen terkait kepuasan terhadap sebuah merek tertentu (Afzal et al., 2010). Fitri (2012) menyatakan bahwa kepercayaan pelanggan adalah penentu signifikan atas ekuitas merek. Hasil empiris lainnya didapat dalam penelitian Chen (2010) yang menunjukkan bahwa kepercayaan hijau berpengaruh positif dan signifikan terhadap ekuitas merek hijau pada produk elektonik Taiwan. Berdasarkan atas kajian penelitian sebelumnya maka dapat dirumuskan hipotesis sebagai berikut:

$\mathrm{H}_{3}$ : Green Trust berpengaruh positif dan signifikan terhadap Green Brand Equty produk Bali Ratih di Kota Denpasar

Semakin kuat green brand image, maka keinginan konsumen untuk ketergantungan pada merek berdasarkan pada rasa yakin pada kemampuan merek tersebut terkait kinerja lingkungannya akan semakin tinggi (Chen, 2010). Penciptaan image sebuah merek adalah penting yang membantu konsumen agar percaya dan memberikan kesan lebih pada konsumen dalam mengingat manfaat penggunaan produk terkait merek yang ramah lingkungan (Dewi, 2014). Studi empiris yang dilakukan oleh Chen (2010) yang berjudul "The Drivers of Green Brand Equity: Green Brand Image, Green Satisfaction, and Green Trust" menunjukkan hubungan antara green brand image dengan green brand equity yang sebagian dimediasi oleh green satisfaction dan green trust. Penelitian yang dilakukan Chen (2010) berfokus padapengaruh dari citra merek hijau pada ekuitas merek hijau, sedangkan kepuasan hijau dan kepercayaan hijau sebagai pemediasi. Berdasarkan atas kajian penelitian sebelumnya maka dapat dirumuskan hipotesis sebagai berikut:

$\mathrm{H}_{4} \quad$ : Green Trust secara signifikan dapat memediasi hubungan antara Green Brand Image Dengan Green Brad Equty produk Bali Ratih di Kota Denpasar

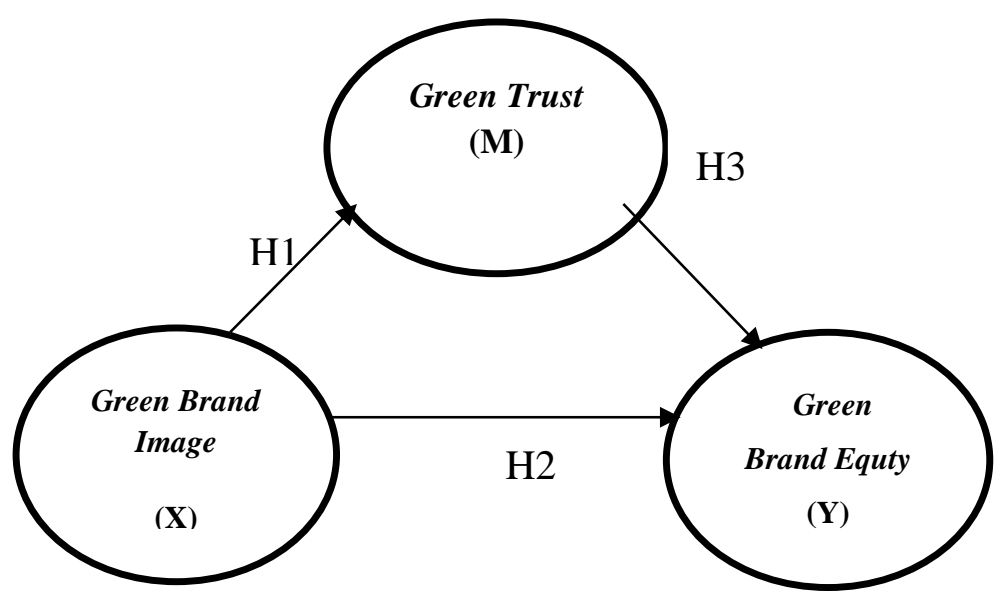

Gambar 1. Desain Penelitian 
Berdasarkan penelusuran kajian pustaka dan hasil-hasil penelitian sebelumnya yang dipaparkan dalam hipotesis maka desain penelitian ini dapat dilihat pada Gambar 1.

Untuk mengetahui pengaruh tidak langsung (H4) maka dilakukan dengan mengalihkan pengaruh $(\mathrm{X}) \mathrm{ke}(\mathrm{M})$ dan $(\mathrm{M})$ ke $(\mathrm{Y})$. dan untuk mendapatkan desain penelitian yang baik, diperlukan desain penelitian agar menunjang dan memberikan hasil penelitian yang sistematik. Penelitian ini menggunakan pendekatan kuantitatif dan kualitatif yang akan dianalisis secara asosiasif. Penelitian asosiasif merupakan penelitian yang bertujuan untuk mencari tahu hubungan atau pengaruh dari satu variabel atau lebih (Sugiyono, 2017: 55). Pada penelitian menjelaskan pengaruh green trust dalam memediasi pengaruh green brand image terhadap green brand equity produk Bali Ratih di Kota Denpasar.

\section{METODE PENELITIAN}

Lokasi dari penelitian ini adalah di Kota Denpasar. Kota Denpasar dipilih dengan alasan bahwa Denpasar adalah daerah urban dengan pertumbuhan sektor ekonomi masyarakatnya yang sangat cepat, dalam hal ini selera masyarakat dapat dipahami dengan jelas. Selain itu, Kota Denpasar dinilai efektif dan efisien dalam menyelenggarakan penelitian yang relevan. Sesuai dengan objek penelitian mengenai merek (brand), perilaku masyarakat Kota Denpasar mencerminkan masyarakat dengan gaya hidup yang lebih memprioritaskan lifestyle dan penampilan. Didukung dengan profesi masyarakat Kota Denpasar yang mengharuskan tampil maksimal, sebagian masyarakat lebih memilih untuk menjaga kualitas kulit tubuhnya untuk selalu terlihat bersih dan sehat dengan menggunakan produk-produk kecantikan yang sudah terjamin kualitasnya dan ramah terhadap lingkungan. Maka dari itu masyarakat di Kota Denpasar akan selektif dalam menggunakan merek dari produk-produk kecantikan yang mengklaim produknya ramah terhadap lingkungan. Dengan pemaparan diatas, penulis mengansumsikan Kota Denpasar dapat menjadi lokasi penelitian yang relevan dan sesuai dengan tujuan dari penelitian ini. Waktu penelitian ini pada tahun 2018. Objek dalam penelitian ini adalah ekuitas merek hijau (green brand equity) pada produk merek Bali Ratih khususnya mengenai hubungan antara citra merek hijau (green brand image) terhadap ekuitas merek hijau (green brand equity) yang dimediasi oleh kepercayaan hijau (green trust).

Seluruh konsumen di Kota Denpasar yang sudah pernah menggunakan produk merek Bali Ratih adalah populasi dalam penelitian ini. Sampel penelitian dikumpulkan menggunakan teknik non probabilitysampling dengan metode purposive sampling, yang didasarkan pertimbangan tertentu. Banyaknya jumlah sampel dalam penelitian ini tergantung dari jumlah parameter yang distimasi. Pedomannya adalah 5-10 kali jumlah parameter yang diestimasi. Dalam penelitian ini menggunakan 14 indikator yang di dasarkan ataskuesioner terkait variabel penelitian, sehingga banyaknya responden yang diambil sebagai sampel adalah $8 \times 14=112$ responden (Sugiyono, 2017:122). Jadi ukuran sampel yang digunakan berjumlah 100 reponden. 
Jenis data yang digunakan dalam penelitian ini yaitu data kuantitatif. Data kuantitaif pada penelitian ini yaitu data dari hasil tanggapan responden terhadap kuisioner yang diberikan sesuai dengan sampel yang sudah ditentukan. Sumber primer dalam penelitian ini diperoleh dari sumbernya langsung, diamati, dan dicatat mengenai pendapat konsumen yang akan dianalisis berdasarkan daftar pertanyaan yang diajukan oleh peneliti dengan menggunakan kuisioner yang dibagikan langsung kepada responden.yang diperoleh atau dikumpulkan oleh peneliti secara langsung dari sumber

Metode dalam pengumpulan data dalam penelitian ini adalah dengan motde survey dengan teknik wawancara menggunakan kuisioner. Selanjutnya kuisioner dalam penelitian ini diukur dengan skala Semantic Differential. Pada skala ini digunakan dalam penelitian ini untuk mengukur sikap yang tersusun dalam satu garis kontinum yang dimana pada jawaban "sangat positif" terletak dibagian kanan garis, sedangkan pada jawaban yang "sangat negatif" terletak pada bagian kiri garis atau sebaliknya (Sugiyono, 2017).

Teknis analisis yang digunakan dalam menganalisis data dalam penelitian ini adalah teknik analisis jalur (path analysis).Persamaan Sub-struktural:

a) Persamaan Sub-struktural I $M=\beta_{1} X+e$.

b) Persamaan Sub-struktural II $\mathrm{Y}=\beta_{2} \mathrm{X}+\beta_{3} \mathrm{M}+\mathrm{e}$.

Keterangan:

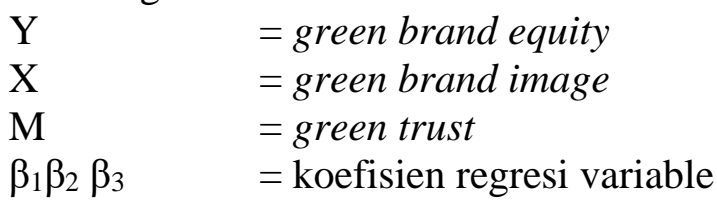

\section{HASIL DAN PEMBAHASAN}

Bali Ratih adalah usaha yang bergerak dalam bidang penjualan produk perawatan tubuh asli dari Bali yang terbuat dari bahan-bahan alami, yang diproses menggunakan teknologi modern yang bersih dan higenis. Dimana di dalamnya terdapat bahan-bahan tradisional pilihan dengan kandungan extract dari sari buah dan tumbuh-tumbuhan menjadikan produk Bali Ratih produk berkualitas terbaik yang aman bagi kulit. Produk Bali Ratih di produksi oleh PT Bali Sari yang beralamat di jalan Purba Indah no 21, Denpasar.

Bali Ratih memiliki empat produk yaitu Traditional Body Scrubs Cream, Body Butter, Hand \& Body Lotion, dan Body Mist. Produk Bali Ratih dijamin bebas dari bahan kimia berbahaya seperti merkuri, hidrokinon, asam retinoat dan pewarna tekstil. Merek ini sudah terkenal dalam industri produk kecantikan ramah lingkungan yang sudah terdaftar di Depkes RI \& BPOM sehingga legal dan sangat aman digunakan. Produk bali Ratih sudah di ekspor ke Korea Selatan, Jepang , Malaysia dan Negara lainnya. 
Data karakteristik responden merupakan data responden yang dikumpulkan untuk mengetahui profil responden penelitian. Karakteristik responden dalam penelitian ini meliputi: usia responden, jenis kelamin dan tingkat pendidikan. Pengukuran tersebut diperoleh dari hasil pengembalian kuesioner penelitian. Karakteristik responden disajikan pada Tabel 2.

Tabel 2.

Karakteristik Responden

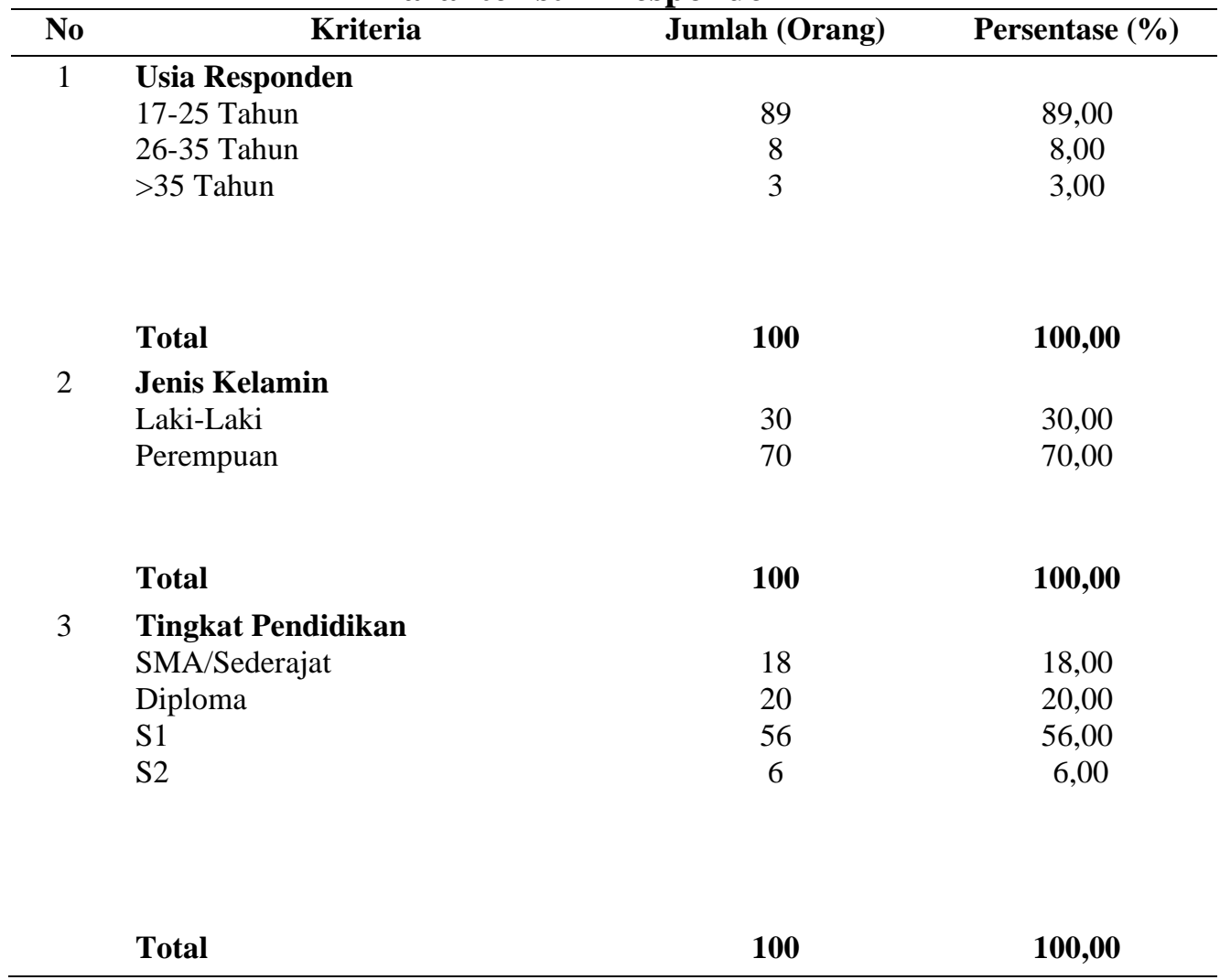

Sumber: Data primer diolah, 2019

Berdasarkan Tabel 2. diketahui bahwa responden dalam penelitian ini adalah konsumen Bali Ratih yang berusia antara 17-25 tahun dengan persentase sebesar 89\% (89 orang), konsumen Bali Ratih yang berusia antara 26-35 tahun dengan persentase sebesar $8 \%$ ( 8 orang), dan 3\% (3 orang) sisanya adalah konsumen Bali Ratih yang berusia lebih dari 35 tahun. Berdasarkan hal tersebut, diketahui konsumen Bali Ratih yang menjadi responden penelitian sebagian besar berada direntang usia antara 17-25 tahun. Konsumen Bali Ratih yang menjadi responden penelitian sebagian besar berjenis kelamin perempuan dengan persentase sebesar $70 \%$ (70 orang) dan sisanya sebanyak 30\% (30 orang) berjenis kelamin laki-laki. Sebagian besar konsumen Bali Ratih yang menjadi dominan memiliki tingkat pendidikan terakhir S1 dengan persentase sebesar 56\% (56 orang), responden dengan tingkat pendidikan terakhir Diploma sebesar 20\% (20 orang), SMA sebesar 
$18 \%$ (18 orang) dan untuk tingkat pendidikan terakhir S2 memiliki persentase sebesar $6 \%$ (6 orang).

Hasil uji validitas instrumen setiap item pernyataan dari masing-masing variabel penelitian memiliki nilai koefisien korelasi yang lebih dari 0,30 dengan tingkat signifikansi kurang dari 0,05 sehingga seluruh item pernyataan pada kuesioner penelitian dapat dinyatakan valid. Sedangkan hasil uji reliabilitas masing-masing variabel penelitian memiliki nilai Cronbach's alpha lebih dari 0,70 sehingga variabel penelitian dapat dinyatakan reliabel.

Penyajian statistik deskriptif dalam penelitian bertujuan untuk memberikan gambaran terkait karakteristik variabel penelitian. Statistik deskriptif dalam penelitian ini disajikan pada Tabel 3.

Tabel 3.

Analisis Statistik Deskriptif

\begin{tabular}{lccccc}
\hline \multicolumn{1}{c}{ Variabel Penelitian } & $\mathbf{N}$ & $\begin{array}{c}\text { Nilai } \\
\text { Minimum }\end{array}$ & $\begin{array}{c}\text { Nilai } \\
\text { Maksimum }\end{array}$ & Mean & $\begin{array}{c}\text { Deviasi } \\
\text { Standar }\end{array}$ \\
\hline Green Brand Equity $(\mathrm{Y})$ & 100 & 1,96 & 4,80 & 4,051 & 0,539 \\
Green Brand Image (X) & 100 & 1,60 & 4,80 & 4,114 & 0,462 \\
Green Trust (M) & 100 & 2,20 & 5,00 & 4,066 & 0,485 \\
\hline
\end{tabular}

Sumber: Data primer diolah, 2018

Berdasarkan Tabel 3. dapat dilihat bahwa berdasarkan atas 4 butir pernyataan yang diberikan diketahui bahwa nilai green brand equity terendah dari tanggapan konsumen Bali Ratih sebesar 1,96 sedangkan nilai green brand equity tertinggi dari tanggapan konsumen Bali Ratih sebesar 4,80. Nilai rata-rata (mean) sebesar 4,051 yang artinya rata - rata konsumen produk Bali Ratih sangat setuju dengan pernyataan mengenai green brand equity dengan kontribusi sebesar 4,051 persen. Nilai standar deviasi sebesar 0,539 yang berarti bahwa rata - rata nilai penyimpangan variabel green brand equity adalah 0,539 persen.

Berdasarkan atas 5 butir pernyataan yang diberikan diketahui bahwa nilai green brand image terendah dari tanggapan konsumen Bali Ratih sebesar 1,60 sedangkan nilai green brand image tertinggi dari tanggapan konsumen Bali Ratih sebesar 5,00. Nilai rata-rata (mean) sebesar 4,114 artinyarata - rata konsumen produk Bali Ratih sangat setuju dengan pernyataan mengenai green brand image dengan kontribusi sebesar 4,114 persen. Nilai standar deviasi sebesar 0,485 yang berarti bahwa rata - rata nilai penyimpangan variabel green brand equity adalah 0,489 persen.

Berdasarkan atas 5 butir pernyataan yang diberikan diketahui bahwa nilai green trust terendah dari tanggapan konsumen Bali Ratih sebesar 2,20 sedangkan nilai green trust tertinggi dari tanggapan konsumen Bali Ratih sebesar 4,80. Nilai rata-rata (mean) sebesar 4,066 yang artinya artinyarata - rata konsumen produk Bali 
Ratih sangat setuju dengan pernyataan mengenai green trust dengan kontribusi sebesar 4,066 persen. Nilai standar deviasi sebesar 0,462 yang berarti bahwa ratarata nilai penyimpangan variabel green brand equity adalah 0,462 persen.

Uji normalitas bertujuan untuk menguji apakah dalam model regresi, variabel terikat dan variabel bebas, keduanya mempunyai data yang terdistribusi normal atau tidak. Model regresi yang baik adalah adalah memiliki distribusi normal atau mendekati normal. Nilai koefisien Kolmogorov-Smirnov persamaan 1 sebesar 1,017 dengan tingkat signifikansi sebesar 0,252 lebih dari 0,05. Hal tersebut berarti bahwa data dari model tersebut telah berdistribusi normal. Nilai koefisien Kolmogorov-Smirnov persamaan 2 sebesar 1,016 dengan tingkat signifikansi sebesar 0,253 lebih dari 0,05. Hal tersebut berarti bahwa data dari model tersebut telah berdistribusi normal.

Uji multikolinieritas bertujuan untuk menguji apakah dalam model regresi terjadi multikolinieritas. Kriteria dari model regresi yang bebas dari gejala multikolinieritas adalah yang memiliki nilai Variance Inflation Factor (VIF) kurang dari 10 dan memiliki nilai Tolerance lebih dari 0,10. Hasil pengujian menyatakan bahwa masing-masing variabel penelitian memiliki nilai tolerance lebih dari 0,10 dan nilai VIF kurang dari 10. Hal tersebut berarti bahwa model regresi tersebut telah bebas dari gejala multikolinearitas.

Uji heteroskedastisitas dilakukan untuk mengetahui apakah nilai residu mempunyai varian yang konstan. Terjadinya heteroskedastisitas dapat diketahui jika nilai residu tidak mempunyai varian yang konstan sepanjang nilai rentang tertentu. Model regresi yang baik adalah yang Homoskesdatisitas atau tidak terjadi Heteroskedastisitas. Terdapat beberapa metode yang dapat digunakan untuk mendeteksi adanya gejala heteroskedastisitas, tetapi dalam penelitian ini akan digunakan uji glejser. Dimana uji ini dilakukan dengan cara meregresi nilai absolute residual. Hasil pengujian untuk persamaan 1 dan persamaan 2 bahwa nilai signifikansi dari variabel bebas lebih dari 0,05 . Hal tersebut berarti bahwa model regresi tersebut bebas dari gejala heteroskedastisitas.

Pengujian hipotesis penelitian dilakukan dengan menggunakan model analisis jalur (path analysis), yaitu analisis jalur (path analysis) digunakan sebagai alat untuk mengolah data penelitiandenganprogram SPSS versi 18 for windows. Hasil pengolahan data dapat dilihat pada Tabel 4. dan Tabel 5.

Tabel 4.

\begin{tabular}{|c|c|c|c|}
\hline \multicolumn{4}{|c|}{ Hasil Analisis Jalur 1 Pengaruh X terhadap M } \\
\hline M & $=$ & & $0,550 X$ \\
\hline$S(\beta)$ & $=$ & & 0,080 \\
\hline & 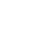 & & 6,520 \\
\hline & $=$ & & 0,000 \\
\hline Sig. $\mathrm{t}$ & $=$ & 0,303 & \\
\hline $\mathrm{R}^{2}$ & $=$ & 0,295 & \\
\hline Adjusted $\left(\mathrm{R}^{2}\right)$ & $=$ & 42,516 & \\
\hline & $=$ & 0,000 & \\
\hline Sig. F & $=$ & & \\
\hline
\end{tabular}

Sumber: Data primer diolah, 2018 
Berdasarkan Tabel 4, maka dapat disusun persamaan struktural yaitu sebagai berikut:

$$
\begin{gathered}
M=\beta_{1} X+e \\
M=0,550 X
\end{gathered}
$$

$$
\begin{aligned}
\operatorname{Error} \operatorname{Term}\left(\mathrm{e}_{1}\right) & =\sqrt{1-R^{2}} \ldots \ldots \ldots \\
& =\sqrt{1-0,303} \\
& =\sqrt{0,697} \\
& =0,835
\end{aligned}
$$

Berdasarkan Tabel 5, maka dapat disusun persamaan struktural yaitu sebagai berikut:

$$
\begin{aligned}
& \mathrm{Y}=\beta_{2} \mathrm{X}+\beta_{3} \mathrm{M}+\mathrm{e} \\
& \mathrm{Y}=0,222 \mathrm{X}+0,559 \mathrm{M}
\end{aligned}
$$

$$
\begin{aligned}
\operatorname{Error} \operatorname{Term}\left(\mathrm{e}_{2}\right) & =\sqrt{1-R^{2}} \ldots \ldots \ldots \\
& =\sqrt{1-0,498} \\
& =\sqrt{0,502} \\
& =0,708
\end{aligned}
$$

Tabel 5.

\begin{tabular}{llcc} 
& Hasil Analisis Jalur 2 Pengaruh X dan $\mathbf{M}$ Terhadap $\mathbf{Y}$ \\
\hline $\mathbf{Y}$ & $\mathbf{0}$ & $\mathbf{0 , 2 2 2}$ & $\mathbf{0 , 5 5 9 M}$ \\
\hline $\mathrm{S}(\beta)$ & $=$ & 0,096 & 0,100 \\
$\mathrm{t}$ & $=$ & 2,574 & 6,486 \\
Sig. $\mathrm{t}$ & $=$ & 0,012 & 0,000 \\
$\mathrm{R}^{2}$ & $=$ & 0,498 & \\
Adjusted $\left(\mathrm{R}^{2}\right)$ & $=$ & 0,487 & \\
$\mathrm{~F}$ & & 48,079 & \\
Sig. F & $=$ & &
\end{tabular}

Sumber: Data primer diolah, 2018

Analisis yang ditujukan untuk mengukur kemampuan variabel bebas dalam nenjelaskan perubahan variabel terikatnya adalah koefisien determinasi. Berdasarkan perhitungan pengaruh eror didapat hasil pengaruh eror jalur $1\left(\mathrm{e}_{1}\right)$ dan pengaruh eror jalur $2\left(\mathrm{e}_{2}\right)$ sehingga koefisien determinasi total adalah sebagai berikut:

$$
\mathrm{R}^{2} \mathrm{~m}=1-\left(\mathrm{e}_{1}\right)^{2}\left(\mathrm{e}_{2}\right)^{2}
$$




$$
\begin{aligned}
& =1-(0,835)^{2}(0,708)^{2} \\
& =1-0,349 \\
& =0,651 \\
& =65,10 \%
\end{aligned}
$$

Hal ini berarti bahwa $65,10 \%$ variasi naik turunnya perubahan green brand equity dipengaruhi oleh variabel bebas green brand image dan variabel mediasi green trust, sedangkan 34,90 \% sisanya dipengaruhi oleh variabel lain yang tidak dijelaskan dalam model.

Penelitian ini menggunakan satu variabel dependen yaitu green brand equity, satu variabel independen yaitu green brand image, dan satu variabel mediasi yaitu green trust.

Pengaruh langsung dari model penelitian ini adalah (1) Pengaruh variabel green brand image $(\mathrm{X})$ terhadap green trust $(\mathrm{M})$ dapat dilihat pada nilai beta dan Standardized coefficient (jalur 1) yaitu sebesar 0,550; (2) Pengaruh variabel green brand image $(\mathrm{X})$ terhadap green brand equity $(\mathrm{Y})$ dilihat pada nilai beta dan Standardized coefficient (jalur 2) yaitu sebesar 0,222; dan (3) Pengaruh variabel green trust $(\mathrm{M})$ terhadap green brand equity $(\mathrm{Y})$ dilihat pada nilai beta dan Standardized coefficient (jalur 2) yaitu sebesar 0,559.

Pengaruh tidak langsung dari model penelitian ini adalah pengaruh variabel green brand image $(\mathrm{X})$ terhadap green brand equity $(\mathrm{Y})$ dengan green trust $(\mathrm{M})$ sebagai variabel mediasi dapat diperoleh dengan rumus sebagai berikut:

$$
\begin{aligned}
& X \longrightarrow M \longrightarrow Y=\left(\beta_{1} \times \beta_{3}\right) \\
& =(0,550 \times 0,559) \\
& =0,307
\end{aligned}
$$

Pengaruh total dari model penelitian ini adalah pengaruh total variabel green brand image $(\mathrm{X})$ terhadap green brand equity $(\mathrm{Y})$ dengan green trust $(\mathrm{M})$ sebagai variabel mediasi. Hasil perhitungan total effect dengan rumus sebagai berikut:

$$
\begin{aligned}
\text { Total effect } & =\text { pengaruh langsung }+ \text { pengaruh tidak langsung } \\
& =\beta_{2}+\left(\beta_{1} \times \beta_{3}\right) \ldots \ldots \ldots \ldots \ldots \ldots \ldots \ldots . \ldots \ldots \ldots \ldots \\
& =0,222+(0,550 \times 0,559) \\
& =0,222+0,307 \\
& =0,529
\end{aligned}
$$

Dari hasil analisis jalur (path analysis), maka dapat dijelaskan terkait uji $\mathrm{F}$ (Uji Kelayakan Model) untuk menghitung koefisien jalur secara keseluruhan.Uji kelayakan model (uji F) dimaksudkan untuk mengetahui apakah dalam penelitian ini, model yang dianalisis layak untuk digunakan. Hasil uji $\mathrm{F}$ dalam penelitian ini disajikan pada Tabel 4. dan Tabel 5. 


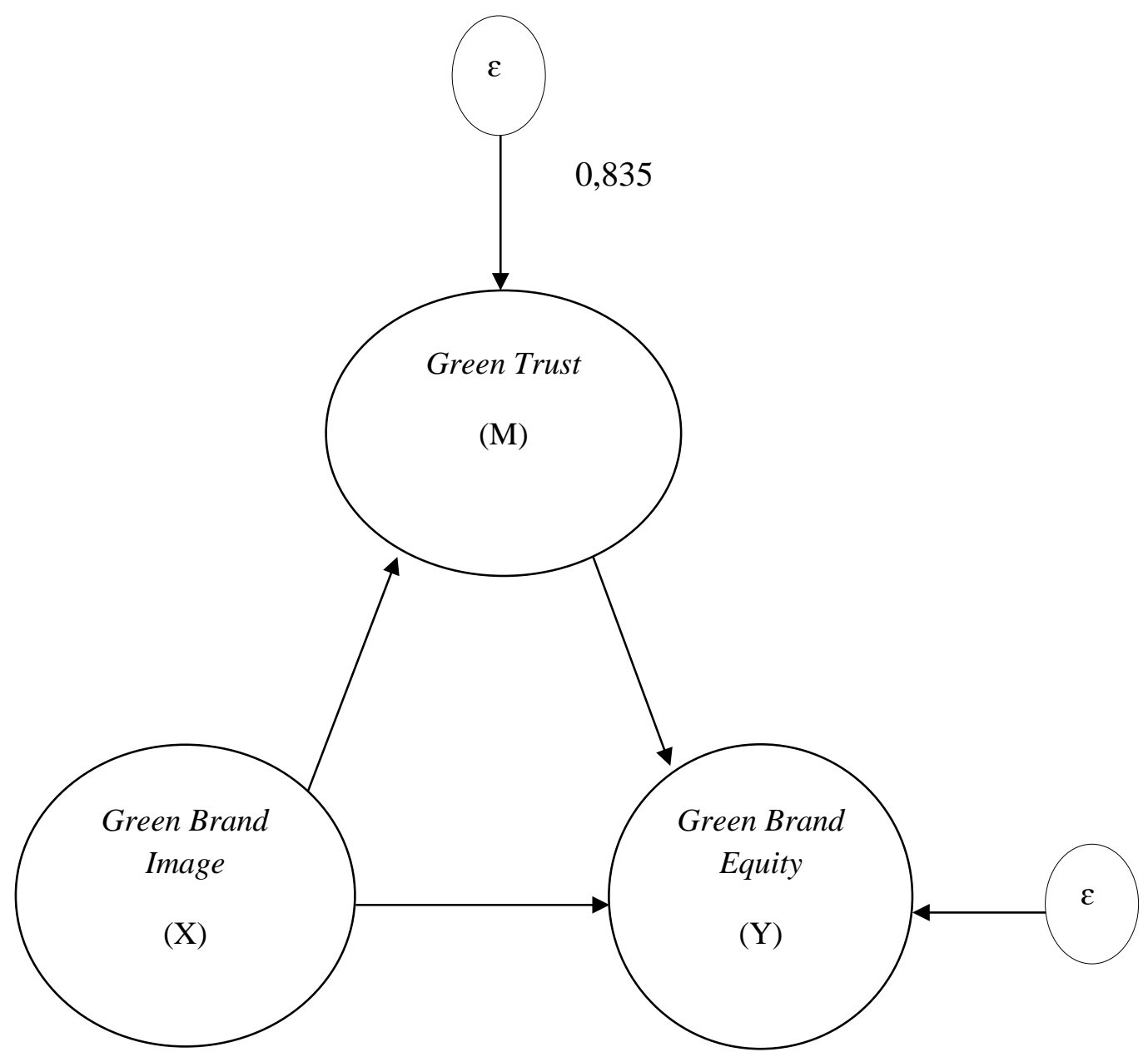

Gambar 2. Koefisien Jalur

Berdasarkan Tabel 4. diketahui bahwa nilai koefisien $\mathrm{F}$ hitung jalur 1 adalah sebesar 42,516 dengan signifikansi sebesar 0,000 kurang dari 0,05. Hal ini berarti bahwa model ini layak untuk dianalisis lebih lanjut.

Berdasarkan Tabel 5. diketahui bahwa nilai koefisien $\mathrm{F}$ hitung jalur 2 adalah sebesar 48,079 dengan signifikansi sebesar 0,000 kurang dari 0,05. Hal ini berarti bahwa model ini layak untuk dianalisis lebih lanjut.

Pada penelitian ini dilakukan sebanyak empat pengujian hipotesis, yang diuraikan sebagai berikut:

Pengujian hipotesis pertama bertujuan untuk menguji pengaruh green brand image pada green trust. Hasil pengujian pada Tabel 4. menunjukkan bahwa koefisien uji t sebesar 6,520 dengan tingkat signifikansi sebesar 0,000 kurang dari 0,05. Hal tersebut berarti bahwa green brand image berpengaruh positif pada green trust, sehingga $\mathrm{H}_{1}$ diterima. 
Pengujian hipotesis kedua bertujuan untuk menguji pengaruh green brand image pada green brand equity. Hasil pengujian pada Tabel 5. menunjukkan bahwa koefisien uji t sebesar 2,574 dengan tingkat signifikansi sebesar 0,012 kurang dari 0,05. Hal tersebut berarti bahwa green brand image berpengaruh positif pada green brand equity, sehingga $\mathrm{H}_{2}$ diterima.

Pengujian hipotesis ketiga bertujuan untuk menguji pengaruh green trust pada green brand equity. Hasil pengujian pada Tabel 5. menunjukkan bahwa koefisien uji t sebesar 6,486 dengan tingkat signifikansi sebesar 0,000 kurang dari 0,05 . Hal tersebut berarti bahwa green trust berpengaruh positif pada green brand equity, sehingga $\mathrm{H}_{3}$ diterima.

Pengujian hipotesis keempat bertujuan untuk menguji pengaruh green brand image pada green brand equity yang dimediasi oleh green trust.

Rumus Uji Sobel yang digunakan adalah :

$$
\mathrm{Zab}=\frac{a b}{S a b}
$$

Dimana:

$$
\begin{array}{ll}
\mathrm{a} & =0,524 \\
\mathrm{~b} & =0,651 \\
\mathrm{Sa} & =0,080 \\
\mathrm{Sb} & =0,100
\end{array}
$$

Sebelum menghitung nilai Zab, maka sebelumnya dihitung terlebih dahulu nilai Sab dengan rumus sebagai berikut:

$$
\begin{aligned}
\mathrm{S}_{\mathrm{ab}} & =\sqrt{\mathrm{b}^{2} \mathrm{Sa}^{2}+\mathrm{a}^{2} \mathrm{Sb}^{2}+\mathrm{Sa}^{2} \mathrm{~S}^{2}} \\
& \left.=\sqrt{\left(0,651^{2} \times 0,080^{2}\right)+\left(0,524^{2} \times 0,100^{2}\right)+\left(0,080^{2} \times 0,100^{2}\right.}\right) \\
& =\sqrt{(0,423 \times 0,006)+(0,274 \times 0,010)+(0,006 \times 0,010)} \\
& =0,0730
\end{aligned}
$$

Dengan demikian nilai Zab dapat dihitung dengan rumus sebagai berikut:

$$
\begin{aligned}
\mathrm{Zab} & =\frac{a b}{S a b} \ldots \ldots \ldots \ldots \ldots \ldots \\
& =\frac{0,524 \times 0,651}{0,0730} \\
& =4,67
\end{aligned}
$$

Dari hasil perhitungan diatas menunjukkan bahwa nilai kalkulasi uji sobel (z) sebesar 4,67 lebih dari $\mathrm{z}$ tabel sebesar 1,96. Hal tersebut berarti green trust merupakan pemediasi pengaruh green brand image pada green brand equity, sehingga $\mathrm{H}_{4}$ diterima 
Hipotesis pertama $\left(\mathrm{H}_{1}\right)$ yang dikemukakan dalam penelitian ini adalah green brand image berpengaruh positif pada green trust. Hasil penelitian menunjukkan bahwa koefisien beta $\left(\beta_{1}\right)$ sebesar 0,524 dengan tingkat signifikansi sebesar 0,000 kurang dari 0,05 . Hal tersebut berarti bahwa green brand image berpengaruh positif pada green trust produk Bali Ratih di kota Denpasar. Semakin baik green brand image yang dimiliki oleh suatu produk, maka semakin baik pula green trust dari produk tersebut. Hasil penelitian tersebut didukung oleh hasil penelitian yang dilakukan oleh Chen (2010), Waluyo dan Didik (2013) yang menyatakan bahwa green brand image berpengaruh positifpada green trust. Konsumen yang memiliki persepsi yangbaik terhadap suatu produk yang memiliki komitmen dan kepedulian yang tinggi terhadap kelestarian lingkungan akan berdampak pada semakin tinggi tingkat kepercayaan yang dimiliki konsumen terhadap suatu produk yang memperhatikan kecakapan lingkungan. Apabila suatu perusahaan telah memperoleh kepercayaan penuh atas produk yang dikeluarkannya, maka perusahaan tersebut akan memiliki nilai lebih di mata konsumennya yang kemudian akan berdampak pada perolehan keuntungan dari perusahaan tersebut (Chen, 2010).

Hipotesis kedua $\left(\mathrm{H}_{2}\right)$ yang dikemukakan dalam penelitian ini adalah green brand image berpengaruh positif pada green brand equity. Hasil penelitian menunjukkan bahwa koefisien beta $\left(\beta_{2}\right)$ sebesar 0,246 dengan tingkat signifikansi sebesar 0,012 kurang dari 0,05. Hal tersebut berarti bahwa green brand image berpengaruh positif pada green brand equity produk Bali Ratih di kota Denpasar. Semakin baik green brand image yang dimiliki oleh suatu produk, maka semakin baik pula green brand equity dari produk tersebut. Hasil penelitian tersebut didukung oleh hasil penelitian yang dilakukan oleh Chen (2010), Waluyo dan Didik (2013) yang menyatakan bahwa green brand image berpengaruh positifpada green brand equity. Menurut Chen (2010), suatu produk yang memiliki image yang kuat dan berkomitmen pada kepedulian lingkungan akan mampu menarik minat konsumen untuk membeli dan menggunakan produk tersebut. Semakin banyak konsumen yang menggunakan produk tersebut maka semakin meningkatkan nilai dari produk tersebut di mata konsumennya.

Hipotesis ketiga $\left(\mathrm{H}_{3}\right)$ yang dikemukakan dalam penelitian ini adalah green trust berpengaruh positif pada green brand equity. Hasil penelitian menunjukkan bahwa koefisien beta $\left(\beta_{3}\right)$ sebesar 0,651 dengan tingkat signifikansi sebesar 0,000 kurang dari 0,05 . Hal tersebut berarti bahwa green trust berpengaruh positif pada green brand equity produk Bali Ratih di kota Denpasar. Semakin tinggi green trust yang dimiliki oleh suatu produk, maka semakin baik pula green brand equity dari produk tersebut. Hasil penelitian tersebut didukung oleh hasil penelitian yang dilakukan oleh Chen (2010), Afzal et al. (2010) dan Fitri (2012) yang menyatakan bahwa green trust berpengaruh positifpada green brand equity. Sebuah kepercayaan memiliki peran penting untuk sebuah brand, karena dengan adanya kepercayaan yang tinggi terhadap suatu brand akan bempak pula pada peningkatan nilai pada brand tersebut (Chen, 2010). Fitri (2012) menyatakan bahwa kepercayaan konsumen adalah penentu yang baik atas nilai suatu merek. Komitmen kepercayaan yang ditunjukkan dengan loyalitas penggunaan produk dapat menjadi indikator bahwa konsumen puas pada merek tersebut (Afzal et al., 2010). 
Hipotesis keempat $\left(\mathrm{H}_{4}\right)$ yang dikemukakan dalam penelitian ini adalah green trust memediasi pengaruh green brand image pada green brand equity. Hasil pengujian menunjukkan bahwa koefisien uji sobel (z) sebesar 4,67 lebih dari z tabel sebesar 1,96. Hal tersebut berarti green trust merupakan pemediasi pengaruh green brand image pada green brand equity produk Bali Ratih di Kota Denpasar. Produk yang memiliki image yang baik terhadap kepedulian lingkungan dan memiliki kepercayaan yang tinggi dari konsumennya tingginya tingkat sosialisasi produk yang dilakukan dapat meningkatkan pula nilai dari produk tersebut. Hasil penelitian ini sejalan dengan hasil penelitian Dewi (2014) yang menyatakan bahwa penciptaan image merek adalah langkah awal untuk membangun kepercayaan konsumen terhadap sebuah merek sebagai sarana untuk membantu konsumen untuk ingat dengan penggunaan produk ramah lingkungan adalah hal yang penting.

Hasil penelitian ini juga mendukung teori green marketing yang menyatakan bahwa perlindungan lingkungan tercermin pada proses penjualan produk dan jasa yang ramah lingkungan. Teori ini mengedepankan praktik pemasaran yang mengutamakan perlindungan lingkungan. Strategi pemasaran dengan membangun image produk yang ramah lingkungan akan membantu membangun kepercayaan konsumen atas keyakinan pada produk tersebut akan aman saat digunakan dan ramah lingkungan, sehingga praktik pemasaran ini tidak hanya menguntungkan perusahaan tetapi juga menguntungkan masyarakat dalam menjaga kelestarian lingkungan.

Penelitian ini mampu menjelaskan model teori tentang pengaruh green brand image pada green brand equity dengan green trust sebagai variabel pemediasi. Hasil penelitian mengungkapkan bahwa pentingnya suatu produk untuk membentuk image positif yaitu salah satunya memiliki kepedulian terhadap lingkungan dan meningkatkan kepercayaan konsumennya untuk tetap menggunakan produk tersebut, sehingga kedua hal tersebut akan membentuk nilai dari brand itu sendiri di mata para konsumennya. Penelitian ini juga menjelaskan bahwa untuk meningkatkan nilai dari suatu produk, maka diperlukan kepercayaan dari para konsumennya yang dapat diwujudkan dengan image dan komitmen dari produk tersebut pada kepedulian lingkungan. Untuk mewujudkan hal tersebut, maka penting untuk setiap perusahaan menerapkan konsep green marketing sebagai bentuk komitmennya dalam mewujudkan sikap kepedulian lingkungan yang tercermin dengan memproduksi produk yang ramah lingkungan.

\section{SIMPULAN}

Berdasarkan rumusan masalah, tujuan, teori, hipotesis dan hasil pengujian yang dilakukan, maka dapat disimpulkan bahwa Green brand image berpengaruh positif pada green trust produk Bali Ratih di kota Denpasar. Green brand image berpengaruh positif pada green brand equity produk Bali Ratih di kota Denpasar. Green trust berpengaruh positif pada green brand equity produk Bali Ratih di kota Denpasar. Green trust merupakan pemediasi pengaruh green brand image pada green brand equity produk Bali Ratih di Kota Denpasar. Produk yang memiliki image yang baik terhadap kepedulian lingkungan dan memiliki kepercayaan yang tinggi dari konsumennya akan mampu meningkatkan nilai dari produk tersebut. 
Saran yang dapat diberikan dalam penelitian ini adalah bagi perusahaan yang memproduksi produk Bali Ratih, sebaiknya lebih memperhatikan indikatorindikator dari green brand image dan green trust yang masih rendah yaitu dalam penggunaan produk Bali Ratih sebagai produk terbaik yang berkomitmen dengan kepedulian lingkungan dan kepercayaan pada produk Bali Ratih terhadap komitmennya dengan kepedulian lingkungan. Atas hasil tersebut, maka dapat disarankan agar perusahaan lebih mengintensifkan promosi produk sehingga konsumen lebih mengenal citra produk dan akan menumbuhkan kepercayaan konsumen pada produk tersebut.

Bagi peneliti selanjutnya diharapkan dapat mengembangkan penelitian terkait green brand equity dengan memperluas wilayah penelitian dan menambahkan variabel lain yang dapat mempengaruhi green brand equity seperti variabel green perceived value.

\section{REFERENSI}

Afzal, H., Khan, M. A., Rehman, K. U., Ali, I., \& Wajahat, S. (2010). Consumer's Trust in the Brand: Can it be Built through Brand Reputation, Brand Competence and Brand Predictability. Journal International Business Research, 3(1), 44-45.

Batu, K. L. (2013). Membangun dan Meningkatkan Citra Perusahaan Melalui Penyebaaran Green Marketing (Penelitian Empiris Di Beberapa Provinsi di Indonesia). Skripsi Fakultas Administrasi Politeknik Negeri Pontianak.

Chen, Y. S. (2010). The drivers of green brand equity: green brand image, green satisfaction, andgreen trust. Journal of Business Ethics, 93(2), 307-319.

Delgado-Ballester, E., \& Munuera-Alemán, J. L. (2005). Does Brand Trust Matter to Brand Equity? Journal of Product and Brand Management, 14(23), 187196.

Dewi, A. I. (2014). Pengaruh Kinerja Green Branding Terhadap Green Brand Preference Pada Industri Green Cosmetics Di Kota Bandung. Jurnal Manajemen Indonesia, 14(3).

Fitri, L. E. (2012). Pengaruh Kepercayaan, Kepuasan Pelanggan dan Komitmen Hubungan Terhadap Ekuitas Merek dan Citra Bank Syariah XYZ di Kota Jambi. Skripsi Fakultas Ekonomi Universitas Jambi.

Shaputra, R. K. (2013). Penerapan Green Marketing Pada Bisnis Produk Kosmetik. Jurnal JIBEKA, 7(3), 47-53.

Sugiyono. (2017). Metode Penelitian Bisnis, Pendekatan Kuantitatif, Kualitatif, Kombinasi, dan R\&D. Yogyakarta: Alfabeta. 
Made Surya Winangun, Peran Green Trust...

Tan, B. C. (2011). The Roles of Knowledge, Threat and PCE on Green Purchase Behaviour. International Journal of Business and Management, 6(12). 